\title{
THE SOVIET VIEWPOINT ON NUCLEAR WEAPONS IN INTERNATIONAL LAW
}

\author{
Peter B. Maggs*
}

... [T] [he initiative in all ventures directed at limiting the miseries of warfart proceeds from Russia. . . the history of missions accomplished by Russia for the good of all peoples convinces us, on the one hand, that the clarification of the basic principles of international law is one of the goals of Russian national policy, and on the other hand, that ultimately the ideas proclaimed by Russia will win general recognition. ... 1

\section{INTRODUCTION}

The Soviet Union, like Tsarist Russia before it, has consistently been in the forefront of the advocates of prohibiting or limiting the use of innovations in weapons of war. ${ }^{2}$ The advantages of this policy have been twofold. First, it has created an image of love of peace and progress that has helped to counteract the unfavorable impression created by the reality of autocratic internal policy and pragmatic foreign policy. Second, the banning of advances in weaponry has served to help the nation retain its relative power position despite its technological backwardness. ${ }^{3}$ The advent of nuclear weapons, followed by the emergence of the Soviet Union as the second super-power has complicated the application of this traditional Russian policy. ${ }^{4}$ The Soviet dialecticians must reconcile the contradictions between Soviet inferiority to United States military might and Soviet superiority to the rest of the world; beween the Soviet peace campaign and the implications of the possession of a nuclear arsenal. ${ }^{6}$

- A.B. 1957, LL.B. 196r, Harvard University. Assistant Professor of Law and Associnte of the Center for Russian Language and Area Studies, University of Illinois. Member of the District of Columbia bar. Research Associate in Law and Associate of the Russian Research Center, Harvard University, 1963-64; exchange student, Leningrad State University, 196r-62. Contributor to legal periodicals.

${ }^{1}$ F. F. Martens, Vostochnaia voina i Briussel'skaia konferentsila $1874-1878$ g. [T'Tite Eastern WAR AND THE BRUSSELS CONFERENCE OF 1874-1878] 99 (1879).

${ }^{2}$ For a history of Russian and Soviet efforts in this area, see O. V. Bogpanov Vsrobshche I polnoe rasoruzhenie (Mezhounarodno-pravovye voprosy) [General and Complete Disarmament (ProdLEMS OF INTERNATIONAL LAW)] $146-65$ ( 1964$)$. Galenin, $K$ istorii voprosa o zapreshchenii varvarskykh sposobov vedeniia voiny [Toward the History of the Problem of Prohibition of Barbaric Means of Waging War], Sovetszoe cosudarstro I pravo [Soviet State and Law; hereinafter cited as SGP], 1953, No. $x$, p. 74, contrasts the Russian approach with American reluctance to adhere to treaty limitations on means of waging war.

${ }^{3}$ A frank discussion of the motives of Nicholas Il's arms control initiatives may be found in WIrre, I Vospominanila; tsarstvovanie Nikolaia II [Memoirs; Reign of Nicholas II] 143 (I922).

- Stalin saw the necessity of combining the traditional Russian policy with an active weapons development program. In 1946 he stated: "Of course the monopoly of the possession of the secret of the atomic bomb creates a threat, but there are at least two answers to it: (a) the monopoly of the possession of the atom bomb cannot last long; (b) the use of the atomic bomb will be prohibited." Pravda, Sept. 25, r946, p. r, col. 5 .

${ }_{5}$ For statistics as to American superiority, see address by President Johnson at the United States Coast Guard Academy, N.Y. Times, June 4, 1964, p. 27, col. 2.

'For a detailed history of Soviet nuclear weapons development, sec Arnold Kramish, Atome EneroY 
The Minitary Use of Nuclear Weapons

Both Soviet weapons policy and Soviet theory of international law form an integrated whole; thus any breakdown for analytical purposes is of necessity artificial. However, a beginning must be made somewhere; an abstract statement that nuclear weapons are legal or illegal means nothing. The question must be put whether or not a given action at a given place and time with respect to these weapons is legal. This article will first discuss the Soviet approach to legal problems connected with the military use of nuclear weapons, and then discuss their testing, construction, possession, stationing, transit, and transfer.

Soviet statements on the military use of nuclear weapons present on the surface a startling dichotomy. Official Soviet spokesmen clearly imply that the Soviet Union is prepared to use nuclear weapons for a variety of military purposes if the need arises and do not intimate that they consider such use unlawful. The Soviet United Nations delegation and Soviet legal scholars, on the other hand, consistently speak and write of the illegality of the use of nuclear weapons.

Soviet civilian and military leaders have been quite explicit about the situations in which they would use their country's nuclear weapons. Both former Chairman Khrushchev and leading Soviet military figures have repeatedly stated that the U.S.S.R., if attacked with nuclear weapons, will reply in kind. In an article published in the Soviet government newspaper, Izvestiia, Marshal Sudets, commander-in-chief of Soviet air defense forces, claimed that the Soviet Union had nuclear-armed antimissile missiles, with which it could destroy attacking missiles before they reached Soviet targets. ${ }^{7}$ In a newspaper interview published in September I96r, Khrushchev stated that either side "would undoubtedly use nuclear weapons" if it felt it was losing in a conventional war unleashed by the "imperialists."

The official manual of naval law published in 1956 by the Soviet Ministry of Defense gives tacit approval to the legality of the use of nuclear weapons against military targets. In its discussion of forbidden weapons, it not only refrains from stating that the use of nuclear weapons is illegal, but specifically points out that no international convention banning their use in time of war exists. ${ }^{9}$ In contrast, aerial bombardment of cities with nuclear weapons is condemned specifically in a later section of the book. ${ }^{10}$ The textbook of international law published in 1964 and officially approved for use in Soviet law schools also refrains from any direct statement that the military use of nuclear weapons is illegal. ${ }^{11}$

in THE Soviet Unton (1959). A chronology of Soviet nuclear test explosions is given in N.Y. Times, July 26 , $x 963$, p. 8 , col. 5 .

${ }^{7}$ Izvestiia, Jan. 5, 1964, p. 2 , col. $x$.

${ }^{8}$ N.Y. Times, Sept. 8, 196I, p. II, col. 2; Pravda, Sept. ro, I96I, p. 3, col. 2.

'Voenno-Morskol mezhdunarono-pravovor spravochnik [NAVAL international LaW HaNdBook] 29x (Bakhov ed. 1956).

${ }^{10}$ Id. at 326.

${ }^{21}$ Mezhdunarodnoe pravo [Internatronat. Law] 647-48 (Kozhevnikov ed. I964). 
In apparent contrast is the position taken by the Soviet Union in the United Nations and by Soviet legal scholars in their unofficial writings. The Soviet Union voted for the General Assembly resolution of November 24, x96x, declaring that the military use of nuclear weapons is illegal. ${ }^{12}$ Soviet legal scholars, instead of developing theoretical justifications for their country's avowed intent to use nuclear weapons in certain circumstances, have unanimously affirmed that the military use of nuclear weapons is illegal. These scholars, including such leading authorities as Bogdanov, ${ }^{13}$ Durdenevskii, ${ }^{14}$ Korovin, ${ }^{15}$ Romashkin, ${ }^{16}$ and Trainin, ${ }^{17}$ are thus in accord with the vast majority of non-Soviet jurists who have written on this issue. ${ }^{18}$ The arguments used by the Soviet jurists are essentially the same as those used by their non-Soviet colleagues. ${ }^{10}$ O. V. Bogdanov, Senior Research Associate of the Institute of State and Law of the Academy of Sciences of the U.S.S.R. puts them as follows: ${ }^{20}$ the use of nuclear weapons violates the "Martens clause" of the Preamble to the IVth Hague Convention of $1907 ;^{21}$ Article 23(d) of the Annex to the Convention; Article 23(a) of the same Annex; the customary international law principle of the prohibition of the direction of military activities against the peaceable civilian populace; the Geneva Convention of 1949 on the Protection of Civilian Persons in Time of War; ${ }^{22}$ the Hague Convention of 1954 on the Protection of Cultural Property in the Event of Armed Conflict; ${ }^{23}$ and the Geneva Protocol Concerning Gas and Bacteriological Warfare of $1925 .{ }^{24}$ Bogdanov, like other Soviet authors, views the use of "tactical" nuclear weapons as being just as illegal as the use of "strategic" nuclear weapons. ${ }^{25}$

12 U.N. Doc. No. A/RES/I653 (XVI) (196r). The history of the Soviet effort to obtain such a declaration is chronicled in BogDANov, op. cit. supra note 2, at 191-203.

${ }^{13}$ Bocdanov, op. cit. supra note 2, at 165-9r.

14 Durdenevskii \& Shevchenko, Nesovmestimost' ispol'zovaniïa atomnogo oruzhiia s normani mezhdunarodnogo prava [The Incompatibility of the Use of Atomic Armament With the Norms of Interna. tional Law], SGP, ז956, No. 5, p. 38 .

${ }^{15}$ Korovin, Atomnoe oruzhie i mezhdunarodnoe pravo [Atomic Armament and International Lasu], Mezhdunarodnaia zhizn' [International Affairs], 1955, No. 5, p. 48.

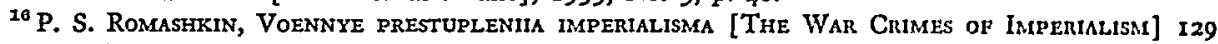
(1953). This work, which was written before Stalin's death and published soon thereafter, was ordered withdrawn from Soviet bookstores sometime before the end of 1955. V. N. BRuk, ALFAvITNYI spnavochnik: ustarevshikh izdanil [Alphabeticaz. Handbook of Obsolete Publications] 242 (1960). The reason for its suppression may have been that its violent anti-Americanism was considered unsuitable in view of the "peaceful coexistence" campaign. See Borisov \& Khaliuta, Book Reviesv, Kommunist [Communist], x954, No. xo, p. xxg.

${ }_{17}$ Trainin \& Morozov, Podgotovka i propaganda atomnoi voiny-tiagchaishee prestupletsic protit chelovechestva [Preparation and Propaganda of Atomic War-The Most Serious Crime Against Humanity], Kommunist [Communist], I955, No. 8, p. 95.

${ }^{28}$ Exhaustive bibliographic citations and summaries of the views of writers on the subject are given in Egerhard Menzel, Legalitït oder Illegalität der Anwendung von Atomwaffen (1960).

${ }^{10}$ E.g., Nagendra Singh, Nuclear Weapons and International LaW (1959); Russian translation with introductory article by $O$. $V$. Bogdanov published under the title IADERNOE ORUzHIE I MEzHDUNARODNOE pravo (1962); but see Georg Schwarzenaerger, The Legality op Nuclear Weapons (1958).

${ }^{20}$ Bogdanov, op. cit. supra note 2, at 165-91.

2136 Stat. 2277; T.S. No. 539 .

${ }^{22}$ [1955] 3 U.S.T. \& O.I.A. 3516 ; T.I.A.S. No. 3365; 75 U.N.T.S. 240.

249 U.N.T.S. 240 .

2494 L.N.T.S. 65.

${ }^{25}$ BogdaNov, op. cit. supra note 2, at 178-79. 
Article I of the limited test ban treaty of 1963 pledges the parties "not to carry out any nuclear weapon test explosion, or any other explosion" in the prohibited environments. ${ }^{26}$ In the hearings on the treaty held by the Senate Foreign Relations Committee, some Senators expressed the fear that this phrase would be interpreted to prohibit the use of nuclear weapons in time of war. ${ }^{2 \pi}$ This argument has not been made in any of the Soviet writings on nuclear weapons that have come to the attention of this author. Indeed, Soviet authors would have little reason to make this argument, since in their view the military use of nuclear weapons was illegal even before the signing and ratification of the test ban treaty. It is somewhat surprising that none of the legal arguments presented to the Foreign Relations Committee (in open session, at least) mentioned the fact that all Soviet legal scholars and many noncommunist legal scholars were of the opinion that the use of nuclear weapons in war was already forbidden by international law.

Both the Soviet-supported General Assembly resolution of November 24, rg6r, and the writings of Soviet legal scholars fail to elaborate upon the implications of the proposition that the military use of nuclear weapons is illegal. No answer is given to such crucial questions as whether or not such weapons may be used in reprisal (a) against a nuclear attack or (b) against an attack with conventional weapons which constitutes aggression in violation of the United Nations Charter, questions which have been given considerable attention by non-Soviet writers. ${ }^{28} \mathrm{~A}$ few words are devoted to this problem in a 1957 article in the authoritative political weekly, New Times, by N. Arkadyev, who is apparently not a lawyer. He argues against the legality of the use of nuclear weapons as a reprisal against aggression, pointing out that a claim of aggression may be used to cover an aggressive intent. ${ }^{29}$

On closer examination the split between the statements of Soviet government leaders and official legal sources on the one hand, and the position of the Soviet United Nations delegation and the legal scholars on the other hand, is more apparent than real. The vague principle of the illegality of nuclear weapons can coexist peaceably with the clear statements of the Soviet generals and politicians preserving their freedom of action in those situations where a credible threat of the use of nuclear weapons is needed. Soviet legal scholars, by refraining from discussing the use of nuclear weapons in retaliation or self-defense, are able to maintain an oversimplified position, which will not stand close examination, but has undoubted appeal to world public opinion. In addition, this approach allows any legal scholars who are opposed to their government's announced position of being the first to use

${ }^{20}$ Treaty Banning Nuclear Weapons Tests in the Atmosphere, in Outer Space and Under Water, Aug. 5, 1963, T.I.A.S. No. 5433.

${ }^{27}$ Hearings on Executive $M$ Before the Senate Committee on Foreign Relations, 88th Cong., Ist Sess. 76-78, I75-79, 201-02 ( 1963$)$.

${ }_{28}$ One legal scholar mentions the problem, but fails to elaborate on it. A. N. Trainin, Zashchita Mira I bor'ba $S$ prestuplemilami protiv chelovechestva [The Defense of Peace and the Struggle With Crimes Against Humanity] 21I (1956). The views of non-Soviet writers are summarized in Menzel, op. cit. supra note 18 at 56-68.

${ }^{20}$ Arkadyev, Nuclear Weapons and International Law, New Times, 1957, No. 4, p. 9. 
nuclear weapons in certain circumstances, ${ }^{30}$ but are afraid to speak out on the subject, to maintain their integrity by silence.

\section{II}

\section{The Peaceful Use of Nuclear Weapons}

In the early stages of their country's nuclear weapons program, Soviet spokesmen placed great emphasis upon the peaceful nature of the uses to which these weapons were to be put. ${ }^{31}$ However, once the Soviet Union achieved substantial nuclear capabilities, this approach was dropped, and the military nature of the Soviet nuclear stockpile was frankly admitted. ${ }^{32}$ More recently, Khrushchev denounced American projects for the peaceful use of nuclear explosions as a cover for weapons development. $^{33}$ Article II of the 1962 Anglo-American draft test ban treaty contained a provision allowing nuclear explosions for peaceful purposes. ${ }^{34}$ Apparently at the insistence of Soviet negotiators, this provision was deleted from the treaty approved in I962. Article I of this treaty prohibits explosions causing "radioactive debris to be present outside the territorial limits of the state under whose jurisdiction or control such explosion is conducted." The effect of this provision is to make impossible the implementation of most previous proposals for the peaceful uses of nuclear explosives. Soviet efforts also were apparently responsible for the insertion in the 1959 Antarctic Treaty of clauses prohibiting peaceful use and testing. ${ }^{35}$

\section{III}

\section{The Testing of Nuclear Weapons}

Both official and unofficial Soviet spokesmen have condemned testing of nuclear weapons by the United States as illegal. A Soviet government statement published in June, 1962 , condemned United States high altitude tests in strong terms: ${ }^{30}$

... the United States Government does not stop and has no intention of stopping at the grossest violations of the elementary norms of international law, which prescribe that states must take the interests of all other states into account in their actions in international affairs.

${ }^{30}$ See the statements cited above, notes 7 and 8 .

${ }^{31} \mathrm{~K}$ RAMISH, op. cit. supra note 6 , at $121-53$.

${ }^{32}$ Id. at 129-32.

${ }^{58}$ N.Y. Times, Sept. 8, 196r, p. Ir, col. I; Pravda, Sept. Io, I96I, p. 3, col. I.

3 Anglo-American Proposal Submitted to the Eighteen Nation Disarmament Committec: Draft Treaty Banning Nuclear Weapons Tests in the Atmosphere, Outer Space, and Underwater, Aug. 27, 1962, printed in United States Arms Control and Disarmament Agency, Documents on Disarmament 1962, 804, at 805 (I963).

${ }^{36}$ S. V. Molodtsov, Dogovor ob Antarktike [The Antarctic Treaty], SGP, 1960, No. 5, p. 64 at p. 68; see generally Kucherov, Sowjetische Ansprïche in der Arktis ttnd Antarktis, 6 Osteuropa-RectrT I23 (1960); compare United States Circular Note Regarding Antarctica, May 3, 1958, 2 U.S. DEp'T of State, Documents on Disarmament I945-1959, at 1020 (I960), with the Antarctic Treaty, Dec. $x$, I959, arts. I and V, [I96I] I U.S.T. \& O.I.A. 794; T.I.A.S. No. $4780 ; 402$ U.N.T.S. 71.

${ }^{36}$ Pravda, June 4, 1962, p. I, col. $x$. 
Soviet legal theorists have gone a step further, and have proclaimed that all American, British and French atmospheric tests have been illegal. ${ }^{37}$

Criticism has centered upon the United States hydrogen bomb tests in the Pacific. The legal objections to these tests were not originated by Soviet jurists. Rather they were first advanced by the parties injured in the United States Pacific test of a thermonuclear device in $1954 .^{38}$ As a result of American miscalculations, a number of the inhabitants of the Trust Territory of the Marshall Islands and a number of Japanese fishermen were injured by fallout from this test. The resulting protests made by Japan to the United States and by the islanders to the United Nations Trusteeship Council were quickly supported by both Soviet official spokesmen and Soviet legal commentators. It is interesting to compare the Soviet writings on this subject with the debate on the same topic published in the Yale Law Journal in 1955..$^{30}$ Professor Margolis opened that debate with the arguments against the tests that were later adopted by the Soviet jurists: the proclamation of closed zones for testing infringes upon the freedom of the seas; the use of the Trust area as a test site violates the agreement under which the United States holds the Marshall islands in trust; the intentional pollution of the sea and air with radioactive fallout violates a developing rule of international law which forbids actions of this type which do harm to other states. Professor McDougal and Mr. Schlei, replying, went extensively into the history of the trusteeship agreement to deny that it limited United States freedom to test. Their main argument, however, is the most interesting, for a mirror image of this argument has been used by Soviet lawyers to support Soviet testing while condemning American testing. McDougal and Schlei argue that the rules of international law are flexible and must be determined in the light of the policy interests involved. They state: $:^{40}$

The claim of the United States is in substance a claim to prepare for self-defense. . . a claim to take certain preparatory measures under conditions comparable to those traditionally held to justify measures in self-defense. It is a claim to take certain actions in contiguous zones and upon the high seas, with the minimum possible interference to others, under conditions of high necessity. ... As expectations of imminent violence in the world arena have become ever more realistic and intense, many of the nations of the free world have organized themselves . . . into regional groupings for their more effective self-defense. The United States has undertaken its program of atomic and thermonuclear weapons development to ensure that these coalitions of free nations are not lacking in retaliatory power which may deter aggression or in weapons of selfdefense if deterrence fails.

${ }^{37}$ E.g., Usachev, Moskovskii dogovor o chastichnom zapreshchenii ispytanii iadernogo oruzhiia ; mezhdunarodnoe pravo [The Moscow Treaty on the Partial Prohibition of the Testing of Nuclear Weaponry and International Law], SGP, 1964, No. 3, p. 72 at p. 73 .

${ }^{38}$ For the history of this incident and its legal repercussions, see Margolis, The Hydrogen Bomb Experiments and International Law, 64 YALE L.J. 629 (1955); McDougal \& Schlei, The Hydrogen Bomb Tests in Perspective: Lawful Measures for Security, 64 YALE L.J. 648 (I955).

as Supra note 38 .

${ }^{10} \mathrm{McD}$ ougal \& Schlei, stipra note 38 , at 686. 
Three Soviet scholars, who have written in detail on the subject of the legality of nuclear testing, Judge Koretskii, ${ }^{41}$ O. V. Bogdanov, ${ }^{42}$ and I. G. Usachev, ${ }^{43}$ have relied upon many of the arguments presented by Professor Margolis to demonstrate the illegality of American hydrogen bomb tests in the Pacific. However, when faced with the difficult question of how to justify continued Soviet testing in view of the harm done by radioactive fallout, the Soviet authors fall back upon argurnents that are just the reverse of those used by McDougal and Schlei. I. G. Usachev, for instance, states: ${ }^{4}$

... and if the Soviet government, for the purposes of strengthening the defense of the U.S.S.R. and the other countries of the socialist system, carried out nuclear tests, this was done in answer to the actions of the Western powers, which forced it to do so.

Thus, before the limited test ban pact was signed, all Soviet and some American commentators took a view which tied the legality of testing to national policy interests, effectively limiting international law restraints upon their own government's actions, while leaving the way open for the imposition of such restraints upon others.

The signing of the limited test ban treaty in 1963 has lessened, though by no means eliminated, the importance of the question of the legality of atmospheric testing under general international law. Two nuclear powers, France and China, have not acceded to the treaty. The most thorough Soviet discussion of the legal implications of the test ban treaty concentrates on the problem of China. ${ }^{45}$ The author of that discussion pointedly quotes Khrushchev's statement, "There has been a sort of world wide plebiscite of governments, political parties and leading statesmen on the question of who is for lessening international tension and who is against." ${ }^{\text {46 }}$ Clearly aimed at China is that author's quotation of the Declaration of the Ig60 Conference of Communist and Workers' Parties with respect to the necessity of achieving a nuclear test ban. ${ }^{47} \mathrm{He}$ does not, however, go so far as to state that a Chinese nuclear test would be a violation of international law.

Soviet legal scholars have presented little worthy of note in their analysis of the legal implications of the test ban treaty itself. O. V. Bogdanov's study, discussed in the preceding paragraph, is largely descriptive. I. G. Usachev, in a short article, makes only two arguments of any interest. He suggests that a state which conducts

${ }^{41}$ Koretskii, $K$ voprosu o protivopravnosti ispytanii termoiadernogo orazhiia $v$ otkrytom more [Toward the Question of the Illegality of Testing Thermonuclear Weapons on the High Seas], Izvestiia vyshikh uchebnykh zavedenii; Pravovedenie [News of Higher Educational Institutions; Jurisprudence], I957, No. I, p. I00.

$\$ 2$ O. V. Bogdanov, Iadernoe Razoruzhenie [Atomic Disarmament] 133 (1961); Bogdanov, Pravovye voprosy prekrashcheniia iadernykh Ispytanii [Legal Questions of fhe Cessation of Nuclear Testing], SGP, I959, No. 7, p. 51 .

18 Usachev, supra note 37 .

st Id. at 75 .

15 Bocdanov, op. cit. supra note 2, at 212-16.

${ }^{10}$ Id. at 213 .

47 Bogdnov, op. cit. supra note 2, at 215. For the text of the Declaration, see N.Y. Times, Dec. 7, 1960, pp. 14-17. 
atmospheric testing in violation of the treaty should be liable for damages caused by fallout, pointing to the United States ex gratia payment to Japan for injuries caused by its 1954 test as a precedent. ${ }^{48}$ Secondly, he ties in the clause in the preamble to the treaty which reads, "Proclaiming as their principal aim the speediest possible achievement of an agreement on general and complete disarmament under strict international control in accordance with the objectives of the United Nations," with the theory expounded by a number of Soviet international lawyers of the existence of a positive legal duty upon all states to agree to complete and general disarmament. ${ }^{49}$

IV

The Construction and Possession of Nuclear Weapons

It is clearly in the interest of the United States, the Soviet Union and the world as a whole to prevent the attainment of nuclear weapons capabilities by countries now lacking them. Obvious dangers, along with possible benefits, are presented by any scheme to give such weapons to international organizations. It is therefore not surprising that an important aim of Soviet foreign policy has been the prevention of the spread of nuclear weapons. Nor is it surprising that the Soviet Union has sought to capitalize upon public aversion to the spread of nuclear weapons by accusing the United States of planning to give control of such weapons to the Federal Republic of Germany. In view of these facts, the restraint of Soviet international lawyers in condemning the spread of nuclear weapons is remarkable; their failure to develop workable concrete proposals for preventing such spread is regrettable.

Soviet legal scholars have never suggested that absent treaty restraints mere possession or construction of nuclear weapons is illegal, though, as mentioned above, there has been considerable discussion of an alleged legal obligation upon all nations to agree to complete and general disarmament. Of the specific treaty restrictions, which apply only to the former Axis powers and their allies, Soviet statements and legal writings have emphasized only the ban on construction of nuclear weapons by West Germany ${ }^{50}$ and the severe restrictions of the Austrian state treaty. ${ }^{\text {bx }}$

Generalizing from the provisions of the latter treaty, which clearly binds Austria not to construct or possess nuclear weapons, Soviet scholars have enunciated the principle that possession of nuclear weapons by a permanently neutral state

${ }^{48}$ Usachev, supra note 37 , at 76 .

${ }^{40}$ Id. at 77-78. See generally Bogdanov, op. cit. supra note 2, at 2I7-32. Romanov, Vseobshchee $i$ polnoe razoruzhenie $i$ mezhdunarodnoe pravo [General and Complete Disarmament and International

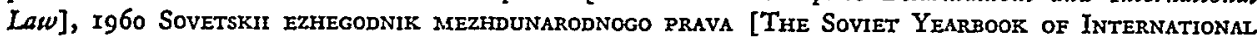
LAw; hereinafter cited as Sov. Yв. INT'L L.] 80 (I96I).

${ }^{\circ}$ Korovin, Mezhdunarodnoe pravo $i$ atomnoe vooruzhenie FRG [International Law and the Atomic Armanent of the German Federal Republic], Mirovaia ekonomika i mezhdunarodnye otnosheniia [World Economics and International Relations], 1958, no. 10, p. 76.

${ }^{51}$ May 15, 1955, art. 13 [1955] 2 U.S.T. \& O.I.A. 2369; T.I.A.S. No. 3298; 217 U.N.T.S. 223. 
is prohibited by international law. Professor Durdinevskii and G. A. Osnitskaia, writing in the leading Soviet legal journal in Ig60, presented the argument that possession of nuclear weapons is incompatible with a status of permanent neutrality, as contradictory to the ideas of peace and cooperation that form the basis of that status. ${ }^{52}$ Nor, they argued, are atomic weapons suitable for defensive purposes, considering the inevitable results of atomic war upon the small territory of the three permanent neutrals-Austria, Switzerland, and Cambodia. ${ }^{53}$ Furthermore, they argued, these small countries could not obtain atomic weapons without foreign aid, and such aid would inevitably come with strings attached that would compromise their neutrality. ${ }^{54}$ The theory was polished a little more in a shorter version of the same article which appeared the next year in the Soviet Yearbok of International Law under Durdenevskii's name alone. ${ }^{55}$ This version emphasized peaceful coexistence and added a paragraph explaining why the Soviet Union needed nuclear weapons while neutral nations did not. ${ }^{56}$

The function of the Soviet legal scholar in this case appears to have been that of an advocate, developing the detailed legal argument for a previously announced government position. A TASS announcement published in August 1958 had strongly protested the Swiss decision to produce atomic weapons and had suggested that the decision was in conflict with the neutral status of Switzerland.57 Then in I959 and I960, the legal scholars presented the detailed arguments discussed above.

Some statements by Khrushchev in $195^{8}$ formed the starting point for an article by the same G. A. Osnitskaia which suggested a much broader concept of atomic neutrality that would apply to neutralist nations and nations in atom-free zones. 58 However, Soviet scholars have not developed this idea of atomic neutrality under international law.

The Soviet Union has consistently opposed the possession of nuclear weapons by the United Nations both now and in a possible disarmed world of the future. In the initial debates on the establishment of a United Nations military force, the U.S.S.R. found itself in agreement with all of the major powers except the United States that such a force, if established at all, should be a weak one. ${ }^{50}$ The Soviet delegate to the Security Council made the quasi-legal argument that any United

sa Durdenevskii \& Osnitskaia, Neitralitet $i$ atomnoe ornzhie [Neutrality and Atomic Armament], SGP, 1960, No. 2, p. Ior.

ss Id. at I04.

os Id. at 104 .

${ }^{\circ}$ Durdenevskii, Neitralitet $i$ atomnoe oruzhie (v svete printsipa mirnogo sosuschchestuovania) [Neutrality and Atomic Armament (In Light of the Principle of Peaceful Coexistence)], 1960 Sov. YB. INT'L L. 105 (Ig6r).

${ }^{\circ 0} I d$. at 107 .

${ }^{87}$ Pravda, Aug. 9, 1958, p. 2, col. 5.

${ }^{6}$ Galina, Problema neitraliteta v sovremennom mezhdunarodnom prave [The Problem of Netutrality in Modern International Law], 1958 Sov. YB. INT'L L. 200 (I959). According to Robert Crane, "Galina" is a pseudonym for "Osnitskaia." Crane, Soviet Attitude Toward International Space Law, 56 An. J. INT'z L. 685,689 n.12 (rg62).

bo Bernard G. Bechioefer, Postwar Negotiations for Arms Control 95-97 (I961). 
Nations military force should be composed "on the basis of the principle of equal contributions." 00 Since at the time of this debate only the United States was in a position to contribute atomic weapons, equal contributions meant no contribution of such weapons.

The proposals that have been advanced in this country to allow possession of nuclear weapons by a United Nations peace-keeping agency in a disarmed world were attacked in a Soviet review of Grenville Clark and Louis Sohn's book, World Peace Through World Law. ${ }^{61}$ The reviewer argued that the retention of such weapons contradicted the principle of complete and general disarmament. ${ }^{62}$

\section{The Stattoning and Transit of Nuclear Weapons}

The Soviet Union participated actively in the negotiation and adoption of the one clear ban upon the stationing and transit of nuclear weapons, that contained in the unanimous General Assembly resolution of October I7, I 963 against stationing nuclear weapons in outer space. ${ }^{63}$ It also gave its support to the General Assembly resolution of November 24, 196x, which called upon member states to "refrain from using the territory, territorial waters or air space of Africa for testing, storing, or transporting nuclear weapons." ${ }^{\text {* }}$ The Soviet Union has also supported many other proposals for denuclearized zones, but with the exception of the outer space resolution, none of these has been acceptable to the United States.

It seems appropriate to discuss here Soviet doctrine with respect to the legal force of General Assembly resolutions. Some Soviet writers state that such resolutions are merely recommendations; this was the view taken in an article published in the January Ig64 issue of the Soviet journal International Affairs with specific reference to the $196 \mathrm{r}$ United Nations resolution against the use of atomic weapons. ${ }^{65}$ Professor G. I. Tunkin, legal advisor to the Soviet Foreign Ministry, goes somewhat further, stating that General Assembly resolutions adopted by a unanimous vote or with the concurrence of the major world power groups can operate as stages in the development of rules of international law. ${ }^{66}$ Other writers, in particular Minasian, would give binding force to such resolutions if they were "democratic" and "directed in the interests of peace" and if they "corresponded to the general principles

${ }^{\circ 0}$ U.N. Securtry Council OFf. Rec. 2d year, I49th meeting II77 (S/PV I49) (1947).

ax Vasiliev, Book Review, SGP, r96I, No. 5, p. 159.

${ }^{03}$ See above, note 49.

${ }^{68}$ U.N. Doc. A/C.I/L.324 [A/RES/I884 (XVIII)], quoted in 49 Dep't State BulL. 754 (1963). See generally Zhukov, Iadernaia demilitarizatsiia kosmosa [Nuclear Disarmament of Outer Space], SGP, 1964 , No. 3, p. 79 .

"U.N. Doc. A/RES/r653 (XVI) (196r).

${ }^{65}$ Lvov, Disarmament Problems in the U.N., International Affairs (Moscow), 1964, No. I, p. I8, at p. 2I; accord, P. I. LUKIN, IstochNiKI MEZHDUNARODNOGo PRAVA [SOURCeS OF INTERNATIONAL LAW] II824 ( 1960$)$.

${ }^{60}$ G. I. Tunkin, Voprosy teoril mezhdunarodnogo prava [Problems of the Theory of Internatronal Law] i34 (1962); accord, Kozhevnikov in Mezhdunarodnoe pravo [International Law] 43 (Kozhevnikov ed., I964). 
of international law."Bt The last-mentioned view, which in effect would allow Soviet spokesmen to pick and choose among General Assembly resolutions, is probably more in accord with the general trend of the Soviet science of international law.

A similar tendency to use selected arguments in favor of the Soviet position is found in studies of the legal status of foreign bases, a problem closely related to the stationing of nuclear weapons. A number of arguments are advanced to explain why American and British bases are illegal, while Soviet bases are legal. The basic point made by many writers is that NATO, CENTO, and SEATO are illegal bo cause their purposes are aggressive. ${ }^{88}$ Judge V. M. Koretskii gave the more detailed arguments that were to become standard in an article published in $1953:{ }^{60}$ the bases are a violation of the sovereignty of the states upon whose territory they are situated; they are meant for uses contrary to the principles of the United Nations Charter; the keeping of bases on United Nations Trust Territories violates trust obligations under Article 76 of the United Nations Charter; the maintenance of bases in West Germany and Japan violates the Cairo and Potsdam declarations; the keeping of bases in Taiwan violates a decision of the Cairo conference.

The Warsaw Pact and the stationing of Soviet troops and weapons in the countries of Eastern Europe are, on the other hand, declared by Soviet spokesmen and scholars to be entirely legal and proper. Unlike the non-Communist alliances, they argue, the Warsaw Pact Organization is a truly regional organization with only defensive goals. It is, they say, therefore quite different from NATO which stretches from the United States to Turkey, and whose treaty provides for military aid to non-signatories. ${ }^{70}$

The Soviet and the American treatment of the legal problems raised by the Soviet Union's stationing of nuclear missiles in Cuba in 1962 and the apparently successful American effort to have them removed are worthy of consideration as illustrations of some of the major similarities and differences in approach to questions of international law.

Both sides recognized the importance of appealing to world public opinion with simple slogans related to principles of international law, though of course the slogans chosen were different. Thus the United States labeled the missiles "offensive" weapons, ${ }^{71}$ while the Soviet Union called them "defensive."

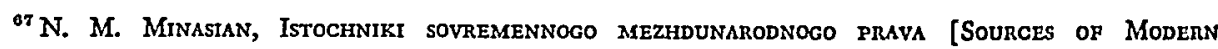
INTERNATIONAL LAW] II2-32 (1960).

${ }^{68}$ M. I. LAZAREV, IMPERIALISTICHESKIE VOENNYE BAZY NA CHUZHIKH TERRITORIAKH 1 MEZHDUNARODNOE pravo [Imperialist Military Bases on Foreign Territory and International Law] 117-20 (1963).

${ }^{89}$ Koretskii, Sozdanie amerikanskikh voennykh baz na chuzhikh territoriakh-narushenie norm mezhdunarodnogo prava [The Creation of American Bases on Foreign Territories is a Violation of the Norms of International Law], SGP, I953, No. 6, p. I20.

${ }^{70}$ MEZHDUNAROdNO-PRAVOVYE FORMY SOTRUDNICHESTVA SOTSIALISTICHESKIKH GOSUDARSTV [INTERNAtional Law Forms of CoOperation of Socialist States] 99-I62 (Shushalov ed. I962).

${ }^{71}$ Radio-Television Address by President Kennedy on the Cuban Crisis, October 22, 1962, 47 Dep'r State BuLl. 715 (1962); Letter From the United States Representative (Stevenson) to the President of the Security Council (Zorin) on the Cuban Crisis, October 22, r962, 47 Dep'T State Bull. 724 
American naval action was called a "quarantine" by the President of the United States; a "blockade," "piracy" and "aggressive" by Soviet spokesmen. ${ }^{73}$ Both sides also used more detailed legal arguments, the case for the United States being presented at length by the Office of the Legal Adviser. ${ }^{74}$

The greatest difference between the American and Soviet treatment of the legal problems came in the area of unofficial comment. In the United States, some unofficial commentators upheld the legality of the use of a threat of force to stop Soviet weapons shipments, ${ }^{75}$ while others questioned the legality of the American measures. ${ }^{78}$ There are no Soviet scholars in a position analogous to that of the law professors who contributed unofficial views in the United States, for all Soviet legal scholars work in institutions and publish in journals controlled by the Soviet party-government establishment. While Soviet authors have repeatedly made clear that their views do not represent those of the Soviet government or Communist Party, they do not in practice differ publicly with official foreign policy or condemn government actions as illegal under international law. The best analogy in United States experience to Soviet scholarly legal writings is found in articles published by United States government lawyers with a disclaimer clause to the effect that "the views expressed herein are those of the individual author and do not necessarily represent the position of his department or of the United States Government." Such authors, like Soviet scholars, are free to discuss questions of international law not settled by official government statement. However, they, like their Soviet counterparts, are subject to many limitations, and do not in practice accuse their government of violating international law. It is appropriate, therefore, to compare the articles on the Cuban crisis published under disclaimer clauses by United States Navy specialists in international law ${ }^{77}$ with an article by a Soviet legal scholar dealing with the same subject. $^{78}$

Both the American and Soviet articles start with the question of the justification of the United States action in the light of the principle of the freedom of the seas and the limitations placed upon the use of force by article 2 of the United Nations

(Ig62); United States Draft Resolution Submitted to the Security Council: Removal of Soviet Missiles From Cub3, October 22, 1962, 47 Dep't State Bull. 724 (1962).

${ }^{2}$ Message From Premier Khrushchev to President Kennedy, October 27, 1962, 47 Dep't State BuLl. 74 I (1962); Message From Premier Khrushchev to President Kennedy, October 28, 1962, 47 DeP'T STATE Bull. 745 (1962). col. 2.

${ }^{78}$ Kennedy, supra note 7I, at 7x6; Soviet Government Statement, N.Y. Times, Oct. 24, I962, p. 20,

"Chayes, The Legal Case for U.S. Action in Cuba, 47 Dep'T State Bulz. 764 (I962); Chayes, Law and the Quarantine of Cuba, $4 \mathrm{x}$ FOREIGN AFFAIRs 554 (1963); Meeker, Defensive Quarantine and the Law, 57 AM. J. INT'L L. 515 (Ig63).

${ }_{75}$ E.g., Larson, Letter to the Editor, N.Y. Times, Nov. I2, 1962, p. 28, col. 5 .

${ }^{70}$ E.g., Wright, The Cuban Quarantine, 57 AM. J. INr'L L. 546 (1963).

${ }^{77}$ Christol \& Davis, Maritime Quarantine: The Naval Interdiction of Offensive Weapons and Associated Matériel to Cuba, 1962, 57 AM. J. INT'L L. 525 (1963); McDevitt, The U.N. Charter and the Cuban Quarantine, I7 JAG J. 7I (1963).

${ }^{73}$ Kolodkin, Morskaia boklada $i$ souremennoe mezhdunarodnoe pravo [Naval Blockade and Contemporary International Law], SGP, I963, No. 4, p. 92. See also Korovin, International Law Through the Pentagon's Prism, International Affairs (Moscow), Dec. 1962, p. 3. 
Charter. The American authors then go on to discuss in detail the possible justifications for the United States action: that the United States was acting in accordance with its right of self-defense under article $5 \mathrm{I}$ of the United Nations Charter or that there was a legitimate regional action under article 52. The Soviet writer condemns the American naval action as an illegal interference with the freedom of the seas and a violation of article 2 of the United Nations Charter, but completely ignores the questions presented by the legal arguments which have been put forth in favor of the United States. Here, as in the case of the question of the legality of the use of nuclear weapons in reprisal against aggression, Soviet international lawyers have refused to enter into a dialogue with their American colleagues, preferring bold arguments that might appeal to legally unsophisticated readers to close analysis of the problems involved.

The proposal to station nuclear weapons on merchant ships to form a multilateral nuclear force has also been attacked as illegal by a Soviet spokesman. Admiral of the Fleet S. Gorshkov, Commander-in-Chief of the Soviet Navy, argues in an article published in May $1963^{79}$ that according to one of the Hague Conventions on the Laws of $\mathrm{War}^{80}$ the use of such rocket launchers disguised as merchant ships would be classified as "brigandage at sea, as piracy which undermines the principle of freedom of the high seas." He goes on to say, "International law allows the destruction of pirate ships and the capture of pirates regardless of their citizenship and the bringing of them to legal responsibility. The Soviet Navy will use its legal rights arising from the Hague Convention."

\section{VI}

\section{The Transfer of Nuclear Weapons}

Since most states are unable to develop their own nuclear weapons because of lack of raw materials, monetary resources, and technical experts, and in view of the limitations of the test ban treaty, restrictions on the transfer of nuclear weapons are crucial to the prevention of their spread. There is no evidence to indicate that the Soviet Union has ever transferred nuclear weapons to any other country. It is less clear whether or not it has ever agreed to make such a transfer. According to a statement of August 15, 1963 by the government of the Chinese People's Republic, a Sino-Soviet agreement on new defense technology of October 15, 1957 bound the Soviet Union to deliver "models of an atomic bomb and technical documents for its production" to China. However, according to the same Chinese statement, the Soviet Union broke this agreement on June 20, $1959 .{ }^{81}$ There is no indication in

\footnotetext{
${ }^{70}$ Izvestiia, May 19, 1963, p. 3, col. 1, at col. 4; Current Digest of the Soviet Press, June 12, 1963, p. 26 (condensed translation).

${ }^{80}$ Admiral Gorshkov is apparently referring to the Convention for the Adaptation to Maritime Warfare of the Principles of the Geneva Convention of July 6, 1906, Oct. 18, 1907, 36 Stat. 2731, T.S. No. 543 and/or the Convention Concerning Bombardment by Naval Forces in Time of War, Oct. $18,1907,36$ Stat. 235I, T.S. No. 542 .

${ }^{81}$ Statement by the Spokesman of the Chinese Government, Aug. 15, 1963, Peking Revicw, Aug. 16, I 963 , p. 7 , at p. I4.
} 
the Chinese statement as to whether or not any nuclear weapons or related technical information were transferred between the dates of the alleged making and breaking of the agreement. However, the Soviet reply to this Chinese statement implies that the U.S.S.R. has not given China any atomic bombs. ${ }^{82}$

The Soviet Union has been cautious in the transfer of control over fissionable material to other countries. Its grants have been of such limited size and nature that they could not form the basis of a significant program of nuclear weapons development in any of the recipient countries. ${ }^{83}$

Despite the obvious interest of the Soviet Union in preventing the spread of nuclear weapons, and the importance of the legal question presented by the Chinese allegation, Soviet legal writers have not developed any theoretical basis for the limitation of such transfers.

\section{Conclusions}

All major powers have long made use of the concepts of international law in their international public relations activities. Since Stalin's death the Soviet leadership has become increasingly aware of the importance of such concepts in the formation of world public opinion. Using legal arguments, it has gained considerable popular support for some of its policies: restraining the United States from using nuclear weapons in local wars, ending Pacific H-bomb tests, and restricting American foreign bases.

However, the U.S.S.R. suffers from a great handicap in the use of international law. This handicap rests in the tight restrictions upon the views which its international law specialists may express in public. As a result of these restrictions, statements by its legal scholars, however sincere and objective, are regarded with suspicion. Furthermore, the leadership runs the risk of conditioning its legal advisors to a way of thinking which will prevent them from giving candid evaluations of legal problems even in private.

Soviet international lawyers are by no means alone in viewing international law as an instrument of government policy to be used, distorted, or discarded as the situation may demand. So long as there is no tribunal with ultimate jurisdiction over questions of international law, we may expect governments, those in their service, and many outside their service to proclaim the invariable legality of their country's foreign policy actions. The Soviet Union thus has little to gain in the struggle to influence world public opinion by forcing its legal scholars to join the ranks of government advocates, for their arguments will be met with equally able counterarguments.

However, while recognizing the fact that the main task of Soviet international law scholars is to defend the foreign policy interests of the U.S.S.R., we should not forget

\footnotetext{
${ }^{83}$ Izvestiia, Aug. 22, I963, p. I, col. 2, at p. 2, col. 6; Current Digest of the Soviet Press, Sept. 18 , 1963 , p. 8 , at p. Io.

${ }^{3}$ Ginsburgs, Soviet Atomic Energy Agreements, 15 International Organization 49 (196r).
} 
that Soviet and American interests often coincide with one another and with the interests of mankind as a whole. No thinking person wants a major nuclear war, wants nuclear weapons to spread, or wants to suffer from the fallout of unlimited testing. There thus remain many areas in which cooperation with Soviet jurists may be possible and constructive in the interests of world peace and security. 